\title{
IDENTIFIKASI BAHAYA DAN PENENTUAN TITIK KENDALI KRITIS PADA UKM KERIPIK NANGKA DI JEMBER
}

\section{Application of Hazard Analysis Critical Control Point (HACCP) System on Jack Fruit Chips SME in Jember}

\author{
Ajun Tri Setyoko \\ Pusat Penelitian dan Pengembangan Standardisasi, Badan Standardisasi Nasional \\ Gedung I BPPT Lantai 12, Jalan M.H. Thamrin No. 8, Jakarta, Indonesia \\ e-mail: ajun_ts@bsn.go.id
}

Diterima: 4 Juli 2018, Direvisi: 26 Juli 2018, Disetujui: 30 Juli 2018

\begin{abstract}
Abstrak
Industri pembuatan keripik nangka di Jember sebagian besar merupakan usaha kecil menengah dengan pengawasan mutu yang belum maksimal, sehingga mutu yang dihasilkan belum konsisten dan belum memenuhi syarat mutu keripik nangka. Untuk menjaga kualitas dan keamanan pangan diperlukan identifikasi bahaya dan penentuan titik kendali kritis selama proses produksi. Tujuan penelitian ini adalah mengidentifikasi bahaya dan penentuan titik kendali kritis proses produksi keripik nangka dan memberikan rekomendasi perbaikan kondisi kerja UKM. Tahapan proses produksi keripik nangka dimulai dari mengupas dan mengiris buah nangka, pencucian daging buah nangka, pembekuan di dalam freezer, pendinginan suhu ruang, penggorengan, pengeringan, pengemasan dan penyimpanan. Dalam pembuatan keripik nangka yang dilakukan oleh UKM di Jember terdapat 2 jenis potensi bahaya yaitu dari segi fisik dan biologis. Berdasarkan hasil identifikasi terdapat 3 proses yang menjadi titik kritis yaitu proses pengupasan dan pengirisan buah nangka, proses pendinginan suhu ruang dan proses pengemasan. Dengan penentuan titik kritis ini, UKM dapat membuat kontrol pada proses tersebut agar produk yang dihasilkan memiliki tingkat keamanan pangan yang baik.
\end{abstract}

Kata kunci: keamanan pangan, HACCP, keripik nangka, UKM

\begin{abstract}
Manufacture of jackfruit chips in Jember is mostly a small and medium enterprises with quality control that has not been maximized, so that the resulting quality has not been consistent and has not fulfilled the quality requirements of jackfruit chips. To maintain food quality and safety hazard identification and determination of critical control points during production process are needed. The purpose of this research is to identify the hazard and determination of critical control point of jackfruit chips production process and to recommend improvement of working conditions of SMEs. The stage of production process of jackfruit chips starts from peeling and slicing fruit jackfruit, leaching jackfruit flesh, freezing in freezer, cooling room temperature, frying, drying, packaging and storage. In making jackfruit chips made by SMEs in Jember there are 2 types of potential hazards, namely in terms of physical and biological. Based on the identification result there are 3 processes that become critical point that is the process of stripping and slicing jackfruit, cooling process of room temperature and packaging process. With the determination of this critical point, SMEs can make control on the process so that the resulting product has a good level of food safety.
\end{abstract}

Keyword: food safety, HACCP, jackfruit chips, SMEs

\section{PENDAHULUAN}

Menurut SNI 01-4269-1996, keripik nangka adalah makanan yang dibuat dari daging buah nangka (Artocarpus integra) masak, dipotong/disayat dan digoreng memakai minyak secara vakum dengan atau tanpa penambahan gula serta bahan tambahan yang diizinkan. Manfaat pengolahan nangka menjadi keripik nangka adalah untuk memberikan nilai tambah dan memperpanjang kemanfaatan buah nangka, selain itu keripik nangka (Didit, 2013).

Industri pembuatan keripik nangka di Jember sebagian besar merupakan usaha kecil menengah dengan pengawasan mutu yang tidak maksimal, sehingga mutu yang dihasilkan belum konsisten dan tidak memenuhi syarat mutu keripik nangka. Berdasarkan survei lapangan yang dilakukan terhadap salah satu UKM keripik nangka di Jember terlihat bahwa UKM tersebut 
belum menerapkan prinsip-prinsip keamanan pangan.

Dalam proses pembuatan keripik nangka terdapat banyak kemungkinan bahaya biologis, seperti cemaran mikroba yang menempel pada buah nangka, bahaya fisik adanya debu-debu halus atau pasir yang ada pada karung, saat material handling yang kurang baik, ataupun bahaya kimia pada proses produksi selama pembuatan keripik nangka. Semua hal tersebut dapat terjadi, namun juga dapat dikendalikan (Yuniarti, 2015).

Untuk memproduksi produk pangan yang aman dikonsumsi, perlu menggunakan standarstandar keamanan pangan (Badan Standarisasi Nasional, 1998). Salah satu standar keamanan pangan yang diakui adalah Hazard Analysis and Critical Control Point (HACCP). HACCP merupakan suatu piranti (sistem) yang digunakan untuk menilai bahaya dan menetapkan sistem pengendalian yang memfokuskan pada pencegahan. HACCP diterapkan pada seluruh mata rantai proses pengolahan produk pangan (Thaheer, 2005).

Program persyaratan dasar merupakan cara produksi makanan yang baik (Good Manufacturing Practice, GMP) atau praktik higiene yang baik (Good Hygiene Practice, GHP) yang akan dipatuhi oleh semua pelaku bisnis makanan, yang memiliki reputasi baik untuk memastikan bahwa makanan yang diberikan pada konsumen adalah makanan yang sehat dan aman (Prasetyo, 2000). Sistem manajemen mutu berfungsi sebagai kerangka acuan yang didalamnya setiap kegiatan proses dapat dikelola, termasuk sistem HACCP (Nurmawati, 2012). Maka dari itu, untuk meningkatkan keamanan pangan pada proses pembuatan keripik nangka ini diperlukan pengamatan dan penerapan HACCP. Pengamatan dan penerapan ini diharapkan mampu mengidentifikasi, menganalisis serta mengendalikan bahaya yang mungkin terjadi pada proses pembuatan keripik nangka.

Tujuan penelitian ini adalah untuk mengidentifikasi bahaya yang terkait selama proses pembuatan keripik nangka serta memberikan rekomendasi untuk mengembangkan sistem HACCP, sehingga menghasilkan produk yang aman untuk dikonsumsi. Dengan produk keripik nangka yang aman dikonsumsi maka sentra industri ini akan dapat bersaing di pasaran serta akan memperkuat potensinya dalam ekonomi nasional.

\section{TINJAUAN PUSTAKA}

HACCP merupakan suatu sistem manajemen pengawasan dan pengendalian keamanan pangan secara preventif yang bersifat ilmiah, rasional dan sistematis dengan tujuan untuk mengidentifikasi, memonitor dan mengendalikan bahaya (hazard) mulai dari bahan baku, selama proses produksi, manufakturing, penanganan dan penggunaan bahan pangan untuk menjamin bahwa bahan pangan tersebut aman bila dikonsumsi (Munarso, 2013).

Dengan demikian dalam sistem HACCP, bahan/materi yang dapat membahayakan keselamatan manusia atau yang merugikan ataupun yang dapat menyebabkan produk makanan menjadi tidak disukai; diidentifikasi dan diteliti dimana kemungkinan besar terjadi kontaminasi atau kerusakan produk makanan mulai dari penyediaan bahan baku, selama tahapan proses pengolahan bahan sampai distribusi dan penggunaannya. Kunci utama HACCP adalah antisipasi bahaya dan identifikasi titik kendali kritis (BSN, 2011).

Menurut Bryan (1992), sistem HACCP didefinisikan sebagai suatu manajemen untuk menjamin keamanan produk pangan dalam industri pengolahan pangan dengan menggunakan konsep pendekatan yang bersifat logis (rasional), sistematis, kontinyu dan menyeluruh (komprehensif) dan bertujuan untuk mengidentifikasi, memonitor dan mengendalikan bahaya yang beresiko tinggi terhadap mutu dan keamanan produk pangan.

Konsep HACCP ini disebut rasional karena pendekatannya didasarkan pada data historis tentang penyebab suatu penyakit yang timbul (illness) dan kerusakan pangannya (spoilage). HACCP bersifat sistematis karena konsep HACCP merupakan rencana yang teliti dan cermat serta meliputi kegiatan operasi tahap demi tahap, tatacara (prosedur) dan ukuran kriteria pengendaliannya. Konsep HACCP juga bersifat kontinyu karena apabila ditemukan terjadi suatu masalah maka dapat segera dilaksanakan tindakan untuk memperbaikinya. Disamping itu, sistem HACCP dikatakan bersifat komprehensif karena sistem HACCP sendiri berhubungan erat dengan ramuan (ingredient), proses dan tujuan penggunaan/pemakaian produk pangan selanjutnya.

Sistem HACCP dapat dikatakan pula sebagai alat pengukur atau pengendali yang memfokuskan perhatiannya pada jaminan keamanan pangan, terutama sekali untuk mengeliminasi adanya bahaya (hazard) yang berasal dari bahaya mikrobiologi (biologi), kimia dan fisika; dengan cara mencegah dan mengantisipasi terlebih dahulu daripada memeriksa/menginspeksi saja. Sementara itu, tujuan dan sasaran HACCP adalah memperkecil kemungkinan adanya kontaminasi mikroba pathogen dan memperkecil potensi mereka untuk tumbuh dan berkembang. Oleh karena itu, secara 
individu setiap produk dan sistem pengolahannya dalam industri pangan harus mempertimbangkan rencana pengembangan HACCP. Dengan demikian, setiap produk dalam industri pangan yang dihasilkannya akan mempunyai konsep rencana penerapan HACCP-nya masing-masing disesuaikan dengan sistem produksinya.

Bagi industri pengolahan pangan, sistem HACCP sebagai sistem penjamin keamanan pangan mempunyai kegunaan dalam hal, yaitu: (1) Mencegah penarikan produk pangan yang dihasilkan, (2) Mencegah penutupan pabrik, (3) Meningkatkan jaminan keamanan produk, (4) Pembenahan dan pembersihan pabrik, (5) Mencegah kehilangan pembeli/pelanggan atau pasar, (6) Meningkatkan kepercayaan konsumen dan (7) Mencegah pemborosan biaya atau kerugian yang mungkin timbul karena masalah keamanan produk.

Untuk memahami konsep HACCP secara menyeluruh diperlukan adanya kesamaan pandangan terhadap beberapa istilah dan definisi yang dipakai dalam sistem manajemen HACCP, yaitu :

a. Bahaya (hazard)

Bahan biologi, kimia atau fisika, atau kondisi yang dapat menimbulkan resiko kesehatan yang tidak diinginkan terhadap konsumen. Definisikan bahaya atau "hazard" sebagai suatu sifat-sifat biologis/mikrobiologis, kimia, fisika yang dapat menyebabkan bahan pangan (makanan) menjadi tidak aman untuk dikonsumsi.

\section{b. Titik Kendali (Control Point/CP)}

Setiap titik, tahap atau prosedur pada suatu sistem produksi makanan yang dapat mengendalikan faktor bahaya biologi/mikrobiologi, kimia atau fisika.

c. Titik Kendali Kritis (Critical Control Point/CCP)

Setiap titik, tahap atau prosedur pada suatu sistem produksi makanan yang jika tidak terkendali dapat mengakibatkan resiko kesehatan yang tidak diinginkan atau setiap titik, tahap atau prosedur yang jika dikendalikan dengan baik dan benar dapat mencegah, menghilangkan atau mengurangi adanya bahaya.

\section{d. Batas Kritis (Critical Limits)}

Batas toleransi yang harus dipenuhi/dicapai yang menjamin bahwa CCP dapat mengendalikan secara efektif bahaya yang mungkin timbul atau suatu nilai yang merupakan batas antara keadaan dapat diterima dan tidak dapat diterima.

Penerapan sistem jaminan keamanan pangan merupakan persyaratan utama dan terpenting dari seluruh parameter mutu pangan yang ada sehingga keamanan pangan menjadi acuan bagi perdagangan pangan domestik maupun internasional (Winarno, 2002). Hazard Analysis and Critical Control Point (HACCP) adalah suatu sistem kontrol untuk mencegah terjadinya masalah yang didasarkan atas identifikasi titik- titik kritis di dalam tahap penanganan dan proses produksi. HACCP merupakan salah satu bentuk manajemen risiko yang dikembangkan untuk menjamin keamanan pangan dengan pendekatan pencegahan (preventive) (Mortimore dan Wallace, 1998). Penerapan HACCP dapat disederhanakan sampai pada level dimana dapat diintegrasikan pada tahapan proses yang sederhana atau tradisional, dimana pengujian dapat dilakukan secara visual (Amoa-Awua et.al. 1998).

Penerapan HACCP dalam suatu industri pangan bertujuan untuk mencegah terjadinya bahaya, sehingga dapat dipakai sebagai jaminan mutu pangan guna memenuhi tuntutan konsumen. HACCP bersifat sebagai sistem pengendalian mutu sejak bahan baku dipersiapkan sampai produk akhir diproduksi masal dan didistribusikan. Oleh karena itu, dengan diterapkannya sistem HACCP akan mencegah risiko komplain karena adanya bahaya pada suatu produk pangan. Selain itu, HACCP juga dapat berfungsi sebagai promosi perdagangan di era pasar global yang memiliki daya saing kompetitif (Anonim, 2005). Untuk menilai efektifitas tindakan pengendalian yang diusulkan, analisis dilakukan untuk mengidentifikasi kebutuhan untuk persyaratan dasar (prerequisite programme) dan implementasi HACCP di lapangan (Amoa-Awua et al, 2007). Good Agricultural Practices (GAP) dan Good Manufacturing Practices (GMP) merupakan persyaratan dasar (prerequisite) yang harus dipenuhi jika ingin menerapkan HACCP (Maharaj, 2010).

Studi HACCP dapat dilakukan dengan menggunakan Panduan Penyusunan Rencana HACCP yang tertuang dalam BSN-Pedoman 1004-1999 yang meliputi: 1) analisis bahaya dan pencegahannya; 2) identifikasi CCP dalam proses; 3) penetapan batas kritis untuk setiap CCP; 4) penetapan cara pemantauan CCP; 5) penetapan tindakan koreksi; 6) penyusunan prosedur verifikasi, dan 7) penetapan prosedur pencatatan (dokumentasi).

\section{METODE PENELITIAN}

Penelitian dilakukan melalui 3 tahap dengan metode pendekatan survei kepada responden UKM dengan menggali sejumlah informasi terkait produksi keripik nangka. Tahap awal dalam penelitian ini adalah tahap identifikasi, dimana tahap ini dilakukan dengan survei pendahuluan 
untuk mendapatkan gambaran mengenai kondisi sistem produksi dan kondisi awal tata letak fasilitas produksi. Penelitian dilakukan di salah satu UKM di wilayah Kabupaten Jember yang memproduksi keripik nangka pada bulan Agustus 2017. UKM ini sudah memiliki pasar yang cukup besar. Produknya sudah di pasarkan ke Jabodetabek, Malang, Kalimantan dan sudah di ekspor hingga ke Singapura.

Tahap kedua yang dilakukan yaitu pengumpulan data, yang terdiri dari data primer dan data sekunder. Data primer diperoleh melalui pengamatan dan pencatatan secara langsung yang berupa data aspek dalam GMP dan Sanitation Standard Operating Procedure (SSOP), data identifikasi bahaya atau Critical Control Point (CCP) pada proses produksi, serta kondisi awal tata letak fasilitas pabrik. Sedang data sekunder yaitu profil perusahaan, proses produksi, dan deskripsi produk.

Tahap ketiga yaitu pengolahan data dengan melakukan analisis SSOP, GMP, dan
HACCP. Untuk analisis HACCP meliputi deskripsi produk, identifikasi rencana penggunaan, penyusunan bagan alir, konfirmasi bagan alir di lapangan, identifikasi bahaya, penentuan CCP, penentuan batas-batas kritis (critical limits) pada tiap TKK (CCP) untuk rekomendasi perbaikan berdasarkan konsep HACCP (Pramesti, 2013).

\section{HASIL DAN PEMBAHASAN}

Deskripsi produk keripik nangka dan identifikasi kondisi UKM yang diperoleh dari survei pendahuluan ditunjukkan pada tabel 1 dan 2 . Pengamatan juga dilakukan terhadap proses produksi yang dilakukan oleh UKM, untuk menilai praktek pembuatan yang telah dilakukan dengan didasarkan pada standar Good Manufacture Practice (GMP). Kondisi UKM dilihat berdasarkan standar GMP (Sonaru, 2014), ditunjukkan pada tabel 3.

Tabel 1 Deskripsi produksi keripik nangka (diolah dari data primer).

\begin{tabular}{ll}
\hline Spesifikasi & Keterangan \\
\hline Nama Produk & Keripik Nangka \\
Bahan Baku & Buah Nangka \\
Pengolahan & Proses Penggorengan \\
Jenis Kemasan & Kemasan alumunium foil dengan klip \\
Karakteristik Produk & Fisik: padat dan aroma normal, netto 80 gram, 100 gram, 250 gram dan \\
& 5 kg \\
Umur Simpan & Biologi: - \\
Distribusi & Tahan hingga 1 tahun dalam keadaan tertutup \\
Penggunaan Produk & Menggunakan mobil bak terbuka \\
Konsumen & Konsumsi langsung \\
\hline
\end{tabular}

Tabel 2 Identifikasi kondisi UKM keripik nangka (diolah dari data primer).

\begin{tabular}{|c|c|c|}
\hline No. & Aspek SSOP & Penyimpangan \\
\hline 1. & Keamanan air & $\begin{array}{l}\text { Perlunya adanya pembersihan tandon air yang digunakan } \\
\text { untuk penampungan air yang digunakan untuk proses } \\
\text { produksi }\end{array}$ \\
\hline 2. & $\begin{array}{l}\text { Kondisi/kebersihan permukaan yang } \\
\text { kontak dengan makanan }\end{array}$ & $\begin{array}{l}\text { Penggunaan kertas koran sebagai pelapis tempat } \\
\text { penyimpanan sementara saat produk keluar dari proses } \\
\text { penggorengan }\end{array}$ \\
\hline 3. & Pencegahan kontaminasi silang & $\begin{array}{l}\text { Produk berpotensi terjai kontaminasi dari pekerja } \\
\text { Tata letak ruangan masih silang saling antar proses produksi, }\end{array}$ \\
\hline 4. & Kebersihan pek & $\begin{array}{l}\text { Pekerja belum menggunakan sarung tangan, masker dan } \\
\text { penutup kepala, belum ada fasilitas wastafel di ruang produksi }\end{array}$ \\
\hline 5. & $\begin{array}{l}\text { Pencegahan dan Perlino } \\
\text { adulterasi }\end{array}$ & $\begin{array}{l}\text { Penempatan lokasi dan wadah lampu minyak yang kurang } \\
\text { baik }\end{array}$ \\
\hline 6. & Pelabelan dan penyimpanan yang tepat & $\begin{array}{l}\text { Pelabelan yang digunakan belum mencantumkan keterangan } \\
\text { yang jelas mengenai tanggal produksi }\end{array}$ \\
\hline 7. & Pengendalian kesehatan karyawan & Belum ada pengawasan terhadap kesehatan karyawan \\
\hline 8. & Pemberantasan hama & $\begin{array}{l}\text { Belum ada penghalang atau pelindung dalam mencegah } \\
\text { serangga masuk ke dalam ruangan produksi }\end{array}$ \\
\hline
\end{tabular}


Tabel 3 Identifikasi penyimpangan aspek GMP pada produk keripik nangka (diolah dari data primer).

\begin{tabular}{|c|c|c|c|}
\hline No. & Aspek GMP & Aspek GMP & Kriteria \\
\hline 1. & Lokasi & $\begin{array}{l}\text { Lokasi produksi berada pada pemukiman padat } \\
\text { penduduk }\end{array}$ & Minor \\
\hline 2. & Bangunan & $\begin{array}{l}\text { Lantai plester, tembok belum diplester, ruangan bahan } \\
\text { baku dengan ruangan produksi disekat menggunakan } \\
\text { jaring, alur kegiatan produksi masih saling silang, belum } \\
\text { ada pengaturan pintu masuk dan keluar ruangan } \\
\text { produksi }\end{array}$ & Minor \\
\hline 3. & Fasilitas sanitasi & $\begin{array}{l}\text { Belum ada fasilitas wastafel di ruang produksi dan } \\
\text { penempatan toilet berdekatan dengan ruang produksi }\end{array}$ & Minor \\
\hline 4. & Pengawasan proses & Belum ada pengawasan langsung & Minor \\
\hline 5. & Karyawan & $\begin{array}{l}\text { Pekerja belum menggunakan sarung tangan, masker dan } \\
\text { penutup kepala }\end{array}$ & Minor \\
\hline 6. & $\begin{array}{l}\text { Label atau keterangan } \\
\text { produk }\end{array}$ & Belum ada keterangan tanggal dan bulan produksi & Minor \\
\hline 7. & Penyimpanan & $\begin{array}{l}\text { Produk yang sudah dikemas disimpan dalam ruangan } \\
\text { terpisah }\end{array}$ & Minor \\
\hline 8. & $\begin{array}{l}\text { Pemeliharaan dan } \\
\text { program sanitasi }\end{array}$ & Belum ada jadwal pembersihan peralatan produksi & Minor \\
\hline 9. & $\begin{array}{l}\text { Dokumentasi dan } \\
\text { pencatatan }\end{array}$ & Belum memiliki dokumentasi dan pencatatan & Minor \\
\hline 10. & Pelatihan & Karyawan belum memiliki pelatihan terkait GMP & Minor \\
\hline \multicolumn{4}{|c|}{ Keterangan } \\
\hline Minor & \multicolumn{3}{|c|}{$\begin{array}{l}\text { : Tingkat penyimpangan yang kurang serius dan tidak menyebabkan risiko terhadap kualitas keamanan pangan } \\
\text { produkispl: }\end{array}$} \\
\hline Mayor & \multicolumn{3}{|c|}{ : Tingkat penyimpangan yang dapat menyebabkan risiko terhadap kualitas keamanan produkispep } \\
\hline Serius & \multicolumn{3}{|c|}{$\begin{array}{l}\text { : Tingkat penyimpangan yang serius dan dapat menyebabkan risiko terhadap kualitas keamanan produk pangan } \\
\text { dan segera ditindaklanjuti }\end{array}$} \\
\hline
\end{tabular}

Dari tabel 3, masih terdapat beberapa aspek GMP yang dinilai memiliki penyimpangan yang dapat menyebabkan risiko terhadap kualitas keamanan produk pangan. Aspek tersebut meliputi bangunan, fasilitas sanitasi, karyawan, label atau keterangan produk serta pemeliharaan dan program sanitasi.

Setelah itu, pengamatan dilakukan pada pelaksanaan pemenuhan standar keamanan pangan, dengan Hazard Analysis and Critical Control Process (HACCP). HACCP dilakukan pada sistem produksi, dengan hasil analisis sebagai berikut:

\section{a. Identifikasi rencana penggunaan}

Konsumen produk keripik nangka adalah dari kalangan anak-anak hingga orang tua. Produk ini tidak cocok untuk bayi. Keripik nangka ini merupakan jenis produk siap makan atau tanpa ada pengolahan lebih lanjut.

\section{b. Penyusunan bagan alir (Flow Chart)}

Bagan alir yang dibuat berdasarkan pengamatan terhadap proses produksi keripik nangka dapat dilihat pada peta proses operasi atau Operation Process Chart (OPC) dari keripik nangka yang disajikan pada gambar 1 dan tabel 4 untuk jumlah operasi kerja produksi keripik tempe

c. Konfirmasi bagan alir di lapangan.

Konfirmasi bagan alir merupakan pengecekan ulang antara diagram alir yang sudah dibuat dengan proses produksi yang terjadi sesungguhnya.

d. Identifikasi bahaya

Tahap identifikasi bahaya digunakan untuk memberi gambaran mengenai potensi bahaya yang mungkin dapat terjadi dari keseluruhan sistem produksi. Potensi bahaya berasal dari hasil wawancara, data UMKM dan beberapa literatur, diringkas pada tabel 4.

Identifikasi penentuan titik kendali kritis atau critical control point pada proses produksi keripik nangka dilakukan mulai dari pengirisan tempe hingga penyimpanan. CCP dapat ditentukan dengan menggunakan pohon keputusan. 


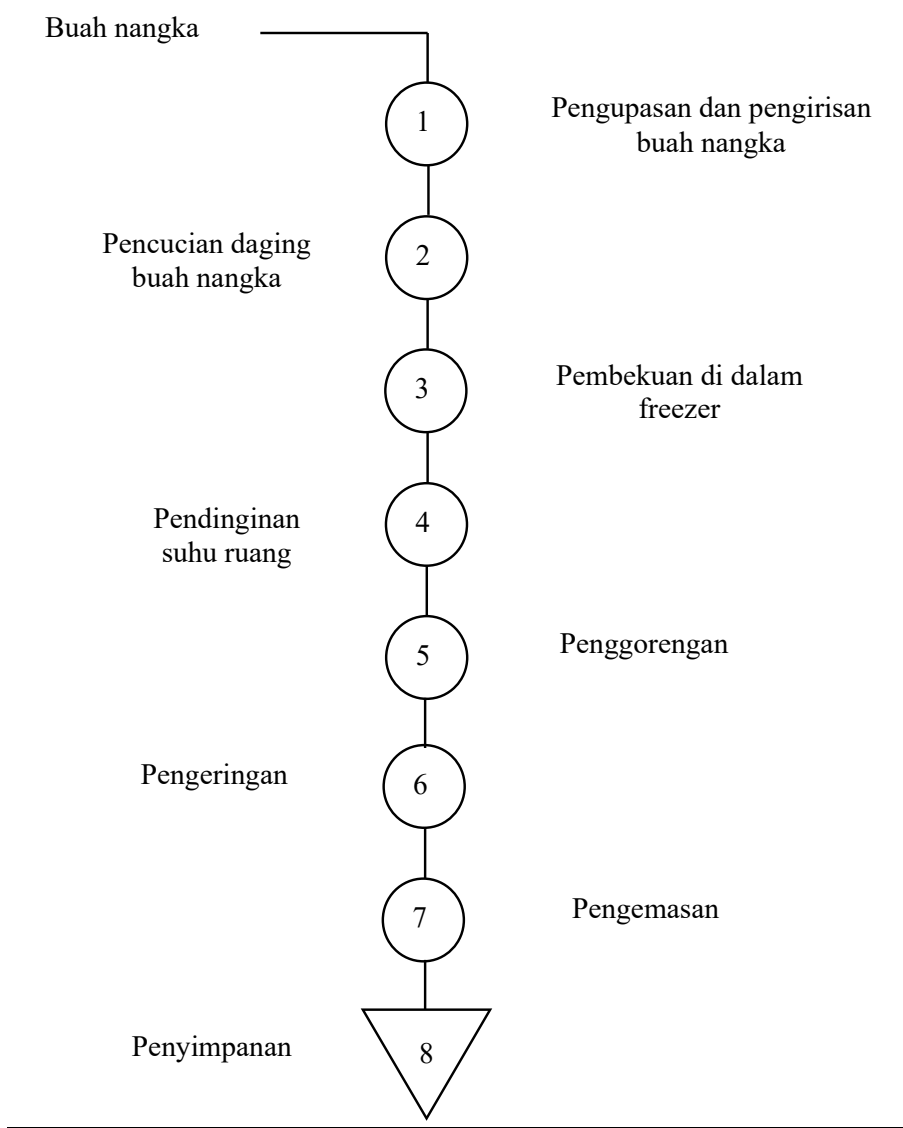

Gambar 1 Diagram alir produksi keripik nangka (diolah dari data primer).

Tabel 4 Identifikasi bahaya pada proses pembuatan keripik nangka (diolah dari data primer).

\begin{tabular}{|c|c|c|c|}
\hline No. & Tahapan Proses & Potensi Bahaya & Keterangan \\
\hline 1. & $\begin{array}{lr}\text { Pengupasan } & \text { dan } \\
\text { pengirisan } & \text { buah } \\
\text { nangka } & \end{array}$ & $\begin{array}{l}\text { Biologis: Kontaminasi tangan pekerja, } \\
\text { mengandung bakteri staphylococcus } \\
\text { aureus } \\
\text { Fisik: Debu, serangga, asap kendaraan } \\
\text { bermotor dari lungkungan luar } \\
\text { Kimia: Tidak ada }\end{array}$ & $\begin{array}{l}\text { - Tempat pengirisan letaknya } \\
\text { yang berada di depan pintu } \\
\text { masuk produksi tanpa pintu } \\
\text { atau penutup } \\
\text { - Karyawan } \\
\text { menggunakan masker, sarung } \\
\text { tangan dan penutup kepala } \\
\end{array}$ \\
\hline 2. & $\begin{array}{ll}\text { Pencucian } & \text { daging } \\
\text { buah nangka }\end{array}$ & $\begin{array}{l}\text { Biologis: Kontaminasi tangan pekerja } \\
\text { mengandung bakteri staphylococcus } \\
\text { aureus } \\
\text { Fisik: Tidak ada } \\
\text { Kimia: Tidak ada }\end{array}$ & $\begin{array}{l}\text { Karyawan belum menggunakan } \\
\text { masker, sarung tangan dan } \\
\text { penutup kepala }\end{array}$ \\
\hline 3. & $\begin{array}{l}\text { Pembekuan di dalam } \\
\text { freezer }\end{array}$ & $\begin{array}{l}\text { Biologis: Tidak ada } \\
\text { Fisik: Tidak ada } \\
\text { Kimia: Tidak ada }\end{array}$ & \\
\hline 4. & $\begin{array}{l}\text { Pendinginan } \\
\text { ruang }\end{array}$ & $\begin{array}{l}\text { Biologis: Kontaminasi bakteri di udara } \\
\text { Fisik: Tidak ada } \\
\text { Kimia: Tidak ada }\end{array}$ & $\begin{array}{l}\text { Daging buah nangka yang telah } \\
\text { dibekukan dibiarkan pada } \\
\text { ruangan terbuka tanpa penutup }\end{array}$ \\
\hline 5. & Penggorengan & $\begin{array}{l}\text { Biologis: Tidak ada } \\
\text { Fisik: Tidak ada } \\
\text { Kimia: Tidak ada }\end{array}$ & Minor \\
\hline 6. & Pengeringan & $\begin{array}{l}\text { Biologis: Tidak ada } \\
\text { Fisik: Tidak ada }\end{array}$ & Minor \\
\hline
\end{tabular}




\begin{tabular}{|c|c|c|c|}
\hline No. & Tahapan Proses & Potensi Bahaya & Keterangan \\
\hline & & Kimia: Tidak ada & \\
\hline 7. & Pengemasan & $\begin{array}{l}\text { Biologis: Kontaminasi tangan pekerja } \\
\text { mengandung bakteri staphylococcus } \\
\text { aureus } \\
\text { Fisik: Debu, serangga, asap kendaraan } \\
\text { bermotor dari lingkungan luar } \\
\text { Kimia: Tidak ada }\end{array}$ & $\begin{array}{ll}\text { - } & \text { Meja pengemasan terlihat } \\
& \text { kotor } \\
\text { - } & \text { Karyawan } \\
& \text { menggunakan masker, sarung } \\
& \text { tangan dan penutup kepala }\end{array}$ \\
\hline 8. & Penyimpanan & $\begin{array}{l}\text { Biologis: Tidak ada } \\
\text { Fisik: Tidak ada } \\
\text { Kimia: Tidak ada }\end{array}$ & $\begin{array}{l}\text { Produk sudah dikemas dalam } \\
\text { kemasan alumunium foil dan } \\
\text { disimpan dalam ruangan } \\
\text { terpisah dan tertutup }\end{array}$ \\
\hline
\end{tabular}

Berdasarkan identifikasi CCP, didapatkan tiga proses yang memiliki CCP yaitu proses pengupasan dan pengirisan nangka, pendinginan dan pengemasan. Berikut ini penjelasannya:

a. Pengupasan dan pengirisan buah nangka.

Proses ini memiliki potensi bahaya yang besar, terutama disebabkan oleh letaknya yang berada di depan pintu masuk produksi tanpa pintu atau penutup sehingga menyebabkan banyak debu dan asap kendaraan bermotor yang berterbangan. Selain itu, kontaminasi pekerja juga terjadi, karena kurang lengkapnya atribut seragam produksi. Hal ini memunculkan sejumlah bakteri yang berbahaya.. Pada proses ini perlu dilakukan pendisiplinan atribut pekerja. Pintu masuk ruangan produksi juga perlu ditutup agar tidak ada kontaminan fisik yang dapat masuk ke dalam ruangan produksi.

b. Pendinginan suhu ruang

Daging buah nangka yang telah dibekukan dibiarkan pada ruangan terbuka tanpa penutup yang berpotensi dapat terkontaminasi oleh bakteri yang ada di udara. Pada proses pendinginan buah nangka ini perlu ditutup dengan rapat agar meminimalkan potensi kontaminasi bakteri yang ada di udara.

c. Pengemasan

Proses ini keripik nangka yang akan dikemas diletakkan pada meja stainless steel. Meja ini terlihat kotor dikarenakan meja tersebut jarang dilakukan pembersihan. Selain itu, pekerja juga belum memakai atribut lengkap yang seharusnya dipakai pada saat proses produksi makanan. Hal ini memiliki potensi memunculkan bakteri pada produk sehingga akan sangat berbahaya bila dikonsumsi. Pada proses ini perlu pendisiplinan atribut pekerja dan jadwal pembersihan fasilitas pengemasan (Sumantri, 2013).

Pengetahuan pekerja akan higienitas dan sanitasi adalah hala yang paling utama. Pemilik UKM perlu memberikan sosialisasi dan arahan tentang keamanan dalam industri. Proses yang merupakan CCP harus dilakukan dengan benar sesuai agar menghilangkan bahaya yang terjadi. Proses yang merupakan CP memerlukan kontrol untuk pencegahan potensi bahaya. Berdasarkan identifikasi bahaya dan titik kendali kritis pada produksi keripik nangka, maka batas kritis untuk mencegah bahaya biologis dan fisik proses pengolahan pangan dapat dilihat pada tabel 5. Pada produksi keripik nangka masih terdapat beberapa proses pengerjaan yang dapat menimbulkan terjadinya risiko terhadap olahan pangan. Risiko yang dapat terjadi antara lain, yaitu tercemarnya olahan pangan dikarenakan karyawan dan peralatan produsi yang tidak higienis dan tata letak ruang produksi yang kurang baik.

Tabel 5 Batas kritis yang ditetapkan pada CCP (diolah dari data primer).

\begin{tabular}{|c|c|c|c|}
\hline No. & Jenis Bahaya & CCP & Batas Kritis \\
\hline 1. & $\begin{array}{l}\text { Bahaya fisik berupa debu, } \\
\text { serangga, asap kendaraan } \\
\text { bermotor dari lungkungan } \\
\text { luar. Bahaya biologis } \\
\text { berupa kontaminasi } \\
\text { bakteri dari tangan pekerja }\end{array}$ & $\begin{array}{l}\text { Proses pengupasan dan pengirisan } \\
\text { buah nangka }\end{array}$ & $\begin{array}{l}\text { - Lokasi pengupasan dan } \\
\text { pengirisan buah nangka } \\
\text { dilakukan pada tempat } \\
\text { yang tertutup } \\
\text { - Karyawan } \\
\text { menggunakan masker, } \\
\text { sarung tangan dan } \\
\text { penutup kepala }\end{array}$ \\
\hline
\end{tabular}




\begin{tabular}{|c|c|c|c|}
\hline No. & Jenis Bahaya & CCP & Batas Kritis \\
\hline 2. & $\begin{array}{l}\text { Bahaya fisik berupa debu, } \\
\text { serangga, asap kendaraan } \\
\text { bermotor dari lungkungan } \\
\text { luar }\end{array}$ & Proses pendinginan suhu ruang & - Penggunaan penutup \\
\hline 3. & $\begin{array}{l}\text { Bahaya fisik berupa debu, } \\
\text { serangga, asap kendaraan } \\
\text { bermotor dari lungkungan } \\
\text { luar. Bahaya biologis } \\
\text { berupa kontaminasi }\end{array}$ & Proses pengemasan & 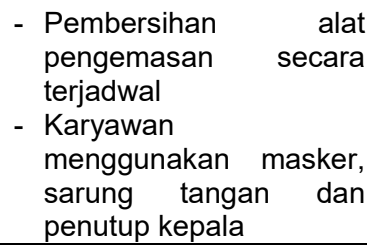 \\
\hline
\end{tabular}

\section{KESIMPULAN}

Dalam pembuatan keripik nangka yang dilakukan oleh UKM di Jember teridentifikasi 2 jenis potensi bahaya yaitu dari segi fisik dan biologis. Berdasarkan hasil identifikasi terdapat 3 proses yang menjadi titik kritis yaitu proses pengupasan dan pengirisan buah nangka, proses pendinginan suhu ruang dan proses pengemasan. Dengan penentuan titik kritis ini, UKM dapat membuat kontrol pada proses tersebut agar produk yang dihasilkan memiliki tingkat keamanan pangan yang baik.

Rekomendasi perbaikan yang dapat diberikan terhadap kondisi kerja yang ada di UKM, yaitu:

a. Rekomendasi terkait hygiene karyawan. Karyawan sebaiknya menggunakan penutup kepala sebagai pelindung olahan pangan dari rambut, masker dan sarung tangan untuk melindungi olahan pangan dari pencemaran bakteri

b. Rekomendasi terkait sanitasi peralatan. UKM perlu membuat jadwal pembersihan peralatan agar peralatan selalu higiene saat digunakan. Pembersihan peralatan mencakup mesin penggoreng, mesin pengering dan meja pengemasan. Hal ini untuk menghindari adanya kontaminasi bakteri saat produk kontak dengan peralatan

c. Rekomendasi terkait bangunan dan tata letak ruang produksi Rekomendasi untuk bangunan pabrik adalah perlu adanya sekat pemisah antara ruangan bahan baku dengan ruangan produksi agar tidak terjadi kontaminasi silang dan dibuat pengaturan pintu masuk dan keluar ruangan produksi. Terkait tata letak fasilitas diusulkan agar ruangan tiap tahap proses produksi dibuat 1 arah dan tidak saling silang sehingga meminimalisir terjadinya kontaminasi silang.

\section{UCAPAN TERIMAKASIH}

Ucapan terima kasih kami sampaikan kepada Pusat Penelitian dan Pengembangan
Standardisasi - Badan Standardisasi Nasional yang telah membiayai penelitian ini melalui APBN Tahun 2017. Ucapan terima kasih juga kami sampaikan kepada anggota tim peneliti dan pihak-pihak yang mendukung penelitian ini.

\section{DAFTAR PUSTAKA}

Amoa-Awua, WK, Halm, A., Jakobsen, M. 1998. HACCP System for African fermented foods : kenkey. Taastrup, Denmark : World Association of Industrial and Tachnological Research Organizations.

Anonim. 2005. Apa itu HACCP. Diakses tanggal $20 \quad$ Oktober 2012 dari Itp.fateta.ipb.ac.id.

Badan Standardisasi Nasional (BSN). 1998. Sistem Analisa Bahaya dan Pengendalian Titik Kritis (HACCP) serta Pedoman Penerapannya. Standar Nasional Indonesia. SNI 01-4852-1998.

(2011). SNI CAC/RCP1:2011 Rekomendasi Nasional Kode Praktis Prinsip Umum Higiene Pangan. Jakarta.

Haryanto, Didit. dkk. 2013. Penyusunan Draft Standard Operating Procedure (SOP) Pengolahan Keripik Pisang (Studi Kasus di Salah Satu Industri Rumah Tangga Keripik Pisang Bandar Lampung). Jurnal Teknologi Industri dan Hasil Pertanian Volume 18 No. 2.

Maharaj, R. 2010. HACCP-based System and The Cocoa Value Chain. University of Trinidad Tobago.

Montimore, S. dan Wallace, C. 1998. HACCP a practical approach. Gaithersburg, Maryland USA. Aspen Publisher Inc.

Munarso, S. Joni dan Miskiyah. 2014. Penerapan Sistem HACCP (Hazard Analysis and Critical Control Points) pada Penanganan Pascapanen Kakao Rakyat. Jurnal Standardisasi Volume 16 Nomor 1, Maret 2014: Hal 17-30.

Nurmawati. 2012. Proses Pembentukan Pola Perilaku Kerja Karyawan PT. Indopherin 
Jaya melalui Budaya Organisasi 5S (Studi Kasus pada Karyawan PT. Indopherin Jaya, Kota Probolinggo. Skripsi. Universitas Brawijaya. Malang.

Pramesti, N. 2013. Analisis Persyaratan Dasar dan Konsep Hazard Analysis Critical Control Point (HACCP) dengan Rekomendasi Perancangan Ulang Tata Letak Fasilitas (Studi Kasus: KUD DAU Malang). Skripsi. Universitas Brawijaya, Malang.

Prasetyo, A.T. 2000, Implementasi GMP dan HACCP dalam Menunjang Quality Assurance Industri Pangan. Skripsi. Universitas Brawijaya, Malang.

Sonaru, A.C. 2014. Analisa Ketidaksesuaian Persyaratan Cara Produksi Pangan yang Baik untuk Industri Rumah Tangga (CPP-
IRT) untuk Meminimalisasi Kontaminasi Produk Roti (Studi Kasus: Perusahaan X). Skripsi. Universitas Brawijaya, Malang.

Sumantri A, 2013. Kesehatan Lingkungan. Jakarta: Kencana Prenada Media Group.

Thahee, H. 2005. Sistem Manajemen HACCP (Hazard Analysis Critical Control Points). Jakarta: PT. Bumi Aksara.

Winarno, FG. 2002. Codex dan SNI dalam Perdagangan Pangan Global. MBRIO Press. Cetakan 1. 75 hal.

Yuniarti, Rahmi dkk. 2015. Penerapan Sistem Hazard Analysis Critical Control Point (HACCP) pada Proses Pembuatan Keripik Tempe. Jurnal IImiah Teknik Industri Volume 14 Nomor 1, Juni 2015 